\title{
BARRIERS AND SUPPORTS IN STARTING FARM-STAY BUSINESSES WITH INBOUND TOURISM EXPERIENCED BY MIGRANTS IN RURAL JAPAN (CASE STUDY OF LOCAL VITALIZATION COOPERATOR ENTREPRENEURS)
}

\author{
Ji Li, Masaya Nakatsuka* \\ Department of Agricultural Engineering and Socio-Economics, Graduate School of Agricultural \\ Science, Kobe University, Kobe, 657-8501, Japan \\ *Corresponding author: nakatsuka@port.kobe-u.ac.jp
}

Citation: Li, J., and Nakatsuka, M. 2021. Barriers and Supports in Starting Farm-stay Businesses with Inbound Tourism Experienced by Migrants in Rural Japan: Case Study of Local Vitalization Cooperation Entrepreneurs. J. Asian Rur. Stud, 5(2): 98-110

\begin{abstract}
The purpose of this study is to clarify the barriers and the process of supports obtained in starting the farm-stay businesses with inbound tourism from the perspective of migrants. Indepth interviews on entrepreneurship of farm-stay businesses among local vitalization cooperators (LVC) were conducted, and the following results were found. First, there are two main types of barriers when starting farm-stay businesses namely barriers caused by new businesses start-up and barriers caused by local life. The barriers caused by local life have three aspects: an inadequate understanding of the ways to interact with local residents, insufficient information on community rules, and insufficient agricultural knowledge. The barriers to receiving foreigners include lack of understanding by neighbors, publicity, service and activities supplied, and matching facilities. Second, supports can also be divided into two categories: supports in local life and those in business start-up. The network and trust relationship established with local residents during the first stage of overcoming local life barriers can help overcome the barriers faced when starting businesses. Meanwhile, supports in business start-up deepen the relationship between migrants and local residents, thus playing a supportive role in life stabilization. Third, by analyzing the LVC cases, we conclude that ordinary migrants need ample time to undergo the process of accommodating to local life, thereby building a network and trust with local regions before starting new businesses. This research provides references on the study of starting new businesses in rural areas from the migrants' views and issues to farm-stay businesses and inbound tourism at the starting phase.
\end{abstract}

Keywords: Farm-Stay Business, Inbound Tourism, Business Startup, Migrant, Barrier, Japan

\section{Introduction}

In recent years, there has been an upward trend in "going back to rural living." This return is no longer the exclusive choice of retirees, but also tends to draw young people who return to rural areas to pursue a better quality of life (Tsutsui et al., 2016). According to the statistics of Furusato Returning Assistance Center (FRAC), an increasing number of people in their $20 \mathrm{~s}$ or $30 \mathrm{~s}$ came for consultation, with the percentage reaching $50.5 \%$ in 2018. 
The biggest concern for young people when migrating to rural areas is the guarantee of work. The working style in rural areas involves not only farming, but also diversified styles of living by using regional resources. Entrepreneurship has become a working style of choice for migrants in rural areas.

Starting tourism and farm-stay businesses using regional resources is favored by young migrants. In recent years, Japanese tourism has witnessed an increasing demand. Tourism needs, including inbound tourism, are diversified, and it is difficult to cope by only relying on local participants. Young migrants, as external talents, have become quite important (Yasumoto, 2014). Migrants can not only realize their own self-value in rural areas, but also flexibly make use of regional resources to create new value using their external perspectives.

In a study on the process of starting businesses and the support system for migrants in villages. Tsutsui et al., (2015) pointed out the importance of communication between local parties and migrants as well as the building of a support system from the rural perspective. From the perspective of supporters, Sakai et al., (2020) analyzed the real situation of support provided by each local entity to migrant entrepreneurship. Most of the studies on the promotion and support of migrant entrepreneurship in rural areas focus on support for the environmental preparation for entrepreneurship from the perspective of regional aspects of rural areas. However, there is a lack of research that focus on the initiatives of rural migrants and the problems in the process of starting businesses from the perspective of migrant entrepreneurs.

In a study on the issues of farm-stay businesses and inbound tourism, Kim et al., (2006) pointed out that there are operational issues such as the cost, labor, and food at the beginning of a farm stay and the allocation of private and public space. Park and Takahashi (2009) pointed out that there exist the issues on manpower support, experience activity menu and publicity during the farm-stay business operating. Tsutsui et al., (2010) and Iwasaki et al., (2017) pointed out that there is a large burden on inbound reception owing to insecurity in such aspects as communication and food supply. Most studies on farm-stay businesses and inbound tourism focus on investigating the operating status of farm-stay businesses run by local residents. As many migrants in rural areas are now choosing to start farm-stay businesses, there is a lack of case studies on the preparation period of starting the farm-stay businesses and inbound tourism by migrants.

As for studies on entrepreneurial barriers, Fielden et al., (2000) pointed out that financial difficulties, time management, inadequate government grants, and business partners are serious barriers to starting new businesses successfully. Sloka et al., (2016) indicated that the serious barriers for business start are infrastructure and unsafe environment, knowledge and skills management, business environment and lack of financial resources. Starting businesses in rural areas differs from that in urban areas. Starting businesses in urban areas, entrepreneurs can conduct value creation activities related to entrepreneurship faster. But for rural entrepreneurship, it is important to understand the rural regional resources and invisible relationship with the rural community and gain trust from local residents at first (Zushi and Odagiri, 2014). However, there has not been any research on the barriers for businesses start in rural areas, particularly on the migrant entrepreneurs' views. 
Many young migrants wish to realize migration by participating in work such as serving as local vitalization cooperators (LVC) Notel) which is related to regional development. In the backdrop of the current trend of young people returning to rural areas, LVC has attracted wide attention as a part of the external talent assistance system rolled out by the national government, witnessing increasing LVCs and implementing municipalities year by year. A survey conducted by the Ministry of Internal Affairs and Communications in 2019 shows that $60 \%$ of the LVCs will settle down in local villages, and one-third of those who do so will start their own businesses. Also, most of them will attempt to start farm-stay or tourism businesses. In a study on the promotion and support systems of LVCs' entrepreneurship and settlement, Shishido and Sanbe (2019), and Kuwabara et al., (2016) pointed out that the establishment of relationships with local administration and residents, as well as the improvement of access and support systems, influence entrepreneurship, and settlement. However, from the perspective of LVCs, there is a lack of research on the troubles and barriers encountered during their entrepreneurship and settlement.

In summary, the research on the barriers to starting businesses, farm-stay businesses and inbound tourism development has pointed out the issues on entrepreneurship in the urban areas and farm-stay businesses entrepreneurship at the operational aspect. However, there is a lack of research on entrepreneurship in the rural areas particularly the research on the difficulties encountered by migrants in starting farm-stay businesses and inbound tourism at the starting phase. The studies on the promotion of migrants' entrepreneurship in the rural areas have pointed out the environmental preparation and support system establishment for entrepreneurship promotion as well as the construction of the relationship with administrative and regional residents from the rural perspective. However, there are still insufficient studies analyzing the problems and solutions in detail from the perspective of migrants. Therefore, this study selects two cases of farm-stay businesses with inbound tourism run by LVC migrants as the research objects to clarify the barriers in starting the farm-stay businesses with inbound tourism, and the process of supports obtained to overcome the barriers from the perspective of migrants. Thus, through the analysis of the cases, we discuss the issues ordinary migrants face when starting businesses, as well as the necessary conditions.

\section{Method}

Since the farm-stay and inbound businesses of migrants are relatively scattered, this research has selected the survey targets of two farm-stay with inbound tourism cases separated in Okumo area, Tambasasayama City, Hyogo Prefecture, and Shimoichi town, Yoshino, Nara Prefecture as well as the migrant entrepreneurs accommodating foreign tourists. Geographically, Okumo area is a rural area located in the eastern part of Tambasasayama City, about an hour's drive from the center of Kyoto and Osaka. Shimoichi town is located in rural area in the central part of Nara Prefecture, also about an hour's drive from the metropolitan area of Kinki area. Both regions are facing a severe population decline and aging problems. Regarding the support institution for migrant entrepreneurs from regional perspective, Tambasasayama city provides migrants with the "vacant house bank" system providing information on vacant houses in the city and entrepreneurship grants for young people. Shimoichi town also has a "vacant house bank" system that provides information on vacant houses, as well as information on operation 
consultations, grants, and financing systems. At the same time, LVCs also enjoy the government's start-up support subsidy. Both regions have adopted an adequate start-up support system in terms of facilities and funds.

This research is based on the perspective of migrant entrepreneurs and tries to master the barriers encountered by them and solutions to the problems in the process of starting farm-stay and inbound businesses. It is difficult to grasp migrants' real thoughts about the process and difficulties of migration and starting a business through fixed questions. To obtain higher quality and more in-depth information, this study uses a non-structured interview with the migrants mainly in the form of free-flowing conversations. A face-toface interview was conducted in November 2019 and an online interview was conducted in April 2020 as the COVID-19 epidemic, respectively, with two migrants who were first LVCs and then started farm-stay businesses with inbound tourism in the rural area for about 90 minutes. The survey content mainly consists of a time-series introduction to the migration and entrepreneurship process, barriers to starting farm-stay businesses and inbound tourism, and the support received in overcoming the barriers. The results of the survey will be extracted and categorized from the responses of the barriers and support received. Finally, the barriers and support structure of the migrants will be discussed.

\section{Results}

\subsection{General Status of Respondents}

As shown in Table 1, A, the owner of the farm-stay in Case 1, was born in Amagasaki City, Hyogo Prefecture, and worked in the service business for 13 years in Tokyo following university graduation. She returned to Hyogo Prefecture in 2017, being the LVC in the Murakumo area of Tambasasayama City. She started up her farm-stay business in the Okumo community in September 2019. The motivation for A to start a farm-stay business was that she desired to engage in all tourism businesses where farmstay is the first step. The owner of the farm-stay in Case 2, B, was born in Saitama City, Saitama Prefecture. She had worked in different companies and performed a variety of jobs (e.g., a teacher and a masseuse). She then went to England to study English and gained a lot of experience. After she returned, she grew increasingly concerned about food and nature and had experience with farm work, which made her go to Nara Prefecture, the cradle of the Japanese civilization. She worked on a plantation for a year and then chose to become a local vitalization cooperator for 3 years. She desired a rural life amidst nature and wanted to create a place where people could gather. She started up the farm-stay business in 2017 after the LVC work. Both of interviewees not only did the farm-stay business with inbound tourism, but also other works. About the experience of contacting foreigners, A served as the guide to the sightseeing of nearly 20 overseas tourist groups during LVC activities with rich experience in inbound tourism. B has overseas education experience in the UK for one and a half years and in Thailand for a month and is quite accustomed to and good at communicating with foreigners.

\subsection{Barriers in Starting the Farm-Stay Business}

As shown in Table 2, the barriers in the start-up stage were mainly of the two types: barriers caused by local life and entrepreneurial preparation. First, as the LVC are the newcomers in the rural area, the barriers in life are the most fundamental. This was reflected in three aspects: an inadequate understanding of the ways to exchange with 
Table 1. General Status of Respondents

\begin{tabular}{lll}
\hline Items & Case 1 & Case 2 \\
\hline Owner & A & B \\
\hline Age; Gender & 30s; Female & 40s; Female \\
\hline Birthplace & Hyogo Prefecture & Saitama Prefecture \\
\hline Migrating place & Tambasasayama City, Hyogo & Yoshino District, Nara \\
\hline $\begin{array}{l}\text { Previous career } \\
\text { and experience }\end{array}$ & $\begin{array}{l}\text { Worked in service industry for 13 } \\
\text { years in Tokyo after university } \\
\text { graduated; LVC in Hyogo (2017-2019) }\end{array}$ & $\begin{array}{l}\text { Various jobs n Tokyo; } \\
\text { Language studying in England; } \\
\text { LVC in Nara (2014-2017) }\end{array}$ \\
\hline $\begin{array}{ll}\text { Motivations for } \\
\text { business starting }\end{array}$ & $\begin{array}{l}\text { Take farm-stay as the starting point to } \\
\text { develop all business of tourism. }\end{array}$ & $\begin{array}{l}\text { Tired of the urban life and } \\
\text { wanted to return to villages; } \\
\text { wants to create a place where } \\
\text { people can gather together }\end{array}$ \\
\hline $\begin{array}{l}\text { Experience of } \\
\text { contacting with } \\
\text { foreigners }\end{array}$ & $\begin{array}{l}\text { received nearly 20 overseas tourist } \\
\text { groups during being LVC as a tour } \\
\text { guide }\end{array}$ & $\begin{array}{l}\text { education experience in the UK } \\
\text { for one and a half years and in } \\
\text { Thailand for a month }\end{array}$ \\
\hline & & $\begin{array}{l}\text { Agroforestry school } \\
\text { coordinator; Coordinator of } \\
\text { Nara Women's University; } \\
\text { Yoga and kids English teacher; }\end{array}$ \\
$\begin{array}{ll}\text { Other work } \\
\text { Coordinator of Europe tour }\end{array}$ \\
\hline Open time & 2019.9 & 2017.4 \\
\hline Source: Authors & survey &
\end{tabular}

Source: Authors' survey

others and attend activities, insufficient information on community systems and rules, and lack of agricultural and rural life knowledge. Based on their answers, we can see that they originally want to live a life at a slow pace, but the life in rural areas is busier and harder. Each community has its own rules, such as village-entry fees and must-attend meetings. Migrants should also frequently meet with local residents and establish a good relationship. According to their responses, actually there is no special meeting in the community to introduce the rules and activities of the community for the migrants. You will feel surprised to find that too many rules and interpersonal relationship to deal with. The unique lifestyle of rural society will impose great burden on them as well.

Second, the barriers generated by starting the farm-stay business mainly consist of capital, seeking and renovating vacant houses, inadequate operation and marketing knowledge, and lack of manpower and consensus acquisition. There is a lack of information on vacant houses on specialized websites, and in fact, quite a few vacant houses were not registered on the websites. Most vacant houses on the website are for sale, but both A and B want to rent house to start the business at first. Moreover, some local residents can offer their houses for living, but unwillingness to offer their houses for the business. Vacant houses in rural areas are mostly dilapidated, and renovating them into houses appropriate for homestay businesses will require a lot of manpower, materials, and capital. 
Table 2. Barriers in Farm-stay Businesses Start-up by Migrants

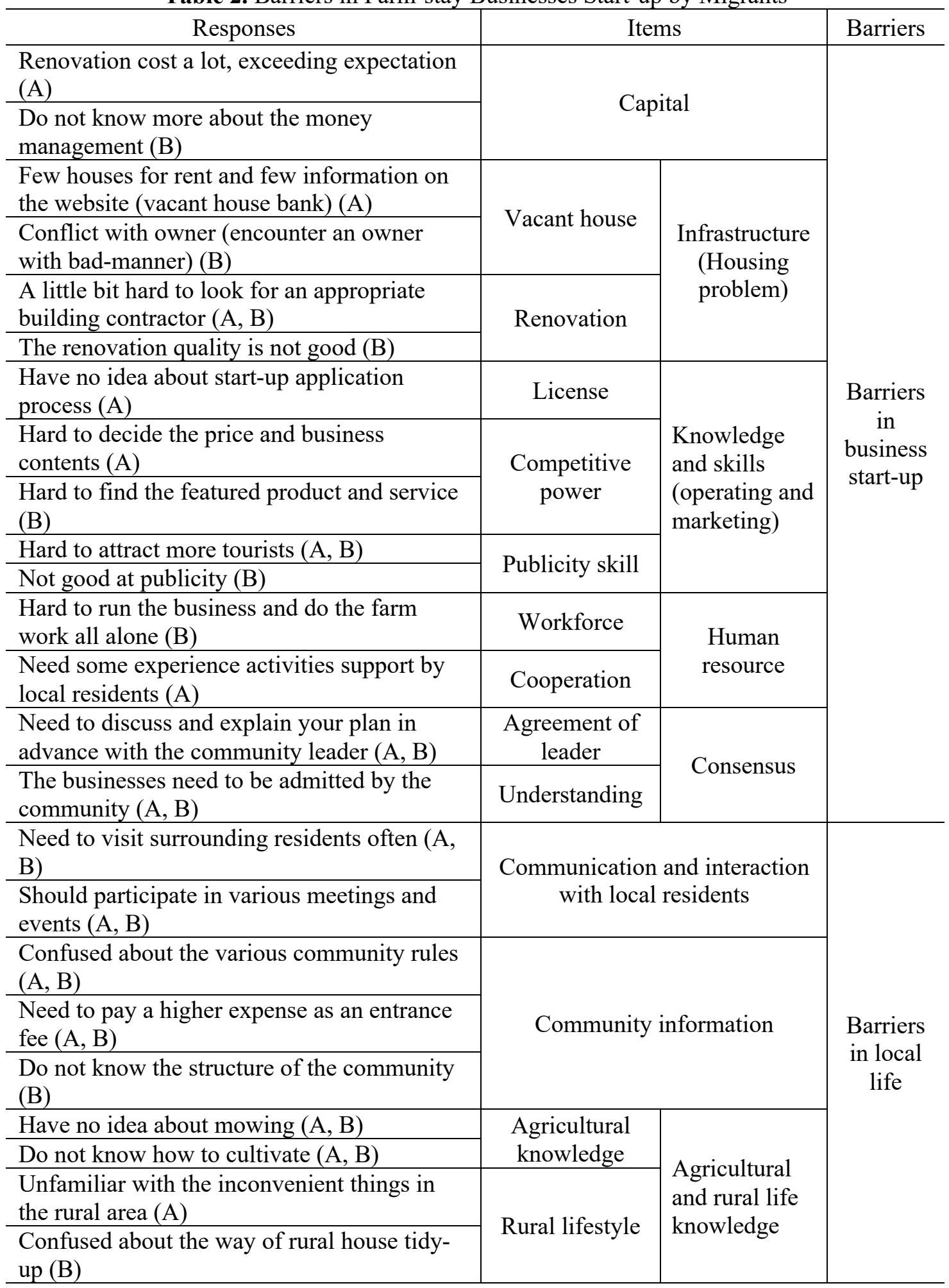

Source: Authors' survey

Regarding marketing skills, a price ceiling matters, but what is more important is how to use local resources to design distinctive, attractive activities and products. Almost all 
the tourists now desire to experience the high-quality tourism products with features in rural areas. Thus, how to balance the service and price is great issue for them to solve. In addition, in contrast to ordinary entrepreneurship in the city, they need to explain their business plans to the head and residents of a community to obtain understanding and permission in advance. Sometimes, the local residents are favorably receiving you to migrating to live in the community, but referring to the business start-up, it would be quite another matter.

\subsection{Supports Received in Starting the Farm-Stay Business}

As shown in Table 3, targeting barriers in local life and the starting of business, the supports received also fall into two aspects: supports in life and in entrepreneurship. First, according to the barriers in the local life, supports received for local life also include three aspects, agriculture and life skill support, local information support and relationship building support. The supports they received for local life are fundamental to step to the business start-up stage. For supports for local life, while serving as LVC, individuals can establish good relations with the local government and local associations. The local government and associations provide suggestions on local life and teach the rules of dealing with local residents. Through their guidance and introduction, migrants can expand their exchanges with local residents and construct a trustworthy relationship with them. The supports in local life have helped migrants prepare well for starting a new business.

Second, among farm-stay business start-up supports, both mainly obtain information from local residents and relevant local business entities through the relationship network established during the supports for local life in the preliminary stage. In particular, the support subjects marked with asterisks $\left(^{*}\right)$ in Table 3 are all derived from the trustworthy relationships established in the supports for local life. These subjects provide them with information on vacant houses and help them reform the house. As the farm-stay business needs to supply the experience activities, surrounding farmers show a favorable cooperation attitude to support the agriculture experience activities. Thus, preparing the business startup enable the local residents to get involved in the farm-stay business. Meanwhile, the supports in business start-up deepened the relationship between migrant entrepreneurs and local residents and local business entities, thus playing a supportive role in stabilizing life in turn.

\subsection{Barriers and Countermeasures in Starting Inbound Tourism}

Since the original aspiration for A and B to start businesses is to offer farm-stay to domestic and overseas tourists, they have prepared to receive overseas tourists when starting businesses. In case 1, since A just started the business for two months during the interview, A had received altogether two groups of foreign tourists from the US and Canada, introduced by others. The number of foreign tourists received in case 2 is approximately one fourth of the total number of tourists, mainly consisting of education tourists and group tourists through travel agencies. As shown in Table 4, in the process of preparing for overseas tourists, there were four main barriers: worrying about the attitudes of people around, publicity, worrying about catering and living habits for foreigners, and imperfect matching facilities. 
Firstly, since the local residents in rural areas rarely communicate with foreigners, the migrants are concerned about the anxiety and attitudes of their neighbors when starting

Table 3. Supports in Farm-stay Businesses Start-up

\begin{tabular}{|c|c|c|c|}
\hline Responses & Sources of support & Items & Supports \\
\hline $\begin{array}{l}\text { Obtained the migrating promotion } \\
\text { subsidy }(\mathrm{A}, \mathrm{B})\end{array}$ & Local government & \multirow{3}{*}{$\begin{array}{l}\text { Financial } \\
\text { support }\end{array}$} & \multirow{11}{*}{$\begin{array}{c}\text { Business } \\
\text { start-up } \\
\text { supports }\end{array}$} \\
\hline $\begin{array}{l}\text { Financial support for LVC } \\
\text { entrepreneur Note2) }(\mathrm{A}, \mathrm{B})\end{array}$ & Local government & & \\
\hline Borrowed money (B) & $\begin{array}{l}\text { Family; Local } \\
\text { residents* }\end{array}$ & & \\
\hline $\begin{array}{l}\text { Got the vacant house information } \\
\text { from local residents }(\mathrm{A}, \mathrm{B})\end{array}$ & Local residents* & \multirow{3}{*}{$\begin{array}{l}\text { Information } \\
\text { support }\end{array}$} & \\
\hline $\begin{array}{l}\text { Reformed the house by local } \\
\text { carpenters through introductions (A, } \\
\text { B) }\end{array}$ & $\begin{array}{l}\text { Local business } \\
\text { entities* }\end{array}$ & & \\
\hline $\begin{array}{l}\text { Obtained help to apply for the } \\
\text { license (B) }\end{array}$ & Local association & & \\
\hline $\begin{array}{l}\text { Received training for business start- } \\
\text { up (A) }\end{array}$ & $\begin{array}{l}\text { Local organization } \\
\text { (Innovators School) }\end{array}$ & \multirow{2}{*}{$\begin{array}{l}\text { Skills and } \\
\text { marketing } \\
\text { support }\end{array}$} & \\
\hline Invited city newspaper to report (A) & Media organizations & & \\
\hline $\begin{array}{l}\text { Local farmers supplied agriculture } \\
\text { experiences (A, B) }\end{array}$ & Local residents* & \multirow{2}{*}{$\begin{array}{l}\text { Manpower } \\
\text { support }\end{array}$} & \\
\hline $\begin{array}{l}\text { Other operators helped to accept } \\
\text { tourists in high season (B) }\end{array}$ & $\begin{array}{l}\text { Local residents of the } \\
\text { same profession* }\end{array}$ & & \\
\hline $\begin{array}{l}\text { Received the approval and } \\
\text { understanding to start-up }(\mathrm{A}, \mathrm{B})\end{array}$ & Local residents* & $\begin{array}{c}\text { Consensus } \\
\text { support }\end{array}$ & \\
\hline $\begin{array}{l}\text { Told me how to associate with local } \\
\text { leader and residents (A, B) }\end{array}$ & Local association & $\begin{array}{l}\text { Relationship } \\
\text { building } \\
\text { support }\end{array}$ & \multirow{7}{*}{$\begin{array}{l}\text { Local life } \\
\text { supports }\end{array}$} \\
\hline $\begin{array}{l}\text { Told me the community rules and } \\
\text { structure }(\mathrm{A}, \mathrm{B})\end{array}$ & $\begin{array}{l}\text { Migrants group; } \\
\text { Local association }\end{array}$ & Local & \\
\hline $\begin{array}{l}\text { Informed me the necessary fee and } \\
\text { activities in the community }(\mathrm{A}, \mathrm{B})\end{array}$ & Local association & $\begin{array}{l}\text { information } \\
\text { support }\end{array}$ & \\
\hline Told me the local wisdom $(\mathrm{A}, \mathrm{B})$ & Local association & & \\
\hline Helped to mow and cultivate (A, B) & $\begin{array}{l}\text { Local residents; local } \\
\text { association }\end{array}$ & \multirow{3}{*}{$\begin{array}{l}\text { Agriculture } \\
\text { and life skill } \\
\text { support }\end{array}$} & \\
\hline Helped to tidy up house (B) & $\begin{array}{l}\text { Local residents; local } \\
\text { association }\end{array}$ & & \\
\hline $\begin{array}{l}\text { Told me the common sense of rural } \\
\text { life }(\mathrm{A}, \mathrm{B})\end{array}$ & Local residents & & \\
\hline
\end{tabular}

inbound businesses. The solution to this problem is to explain and communicate with their neighbors kindly to seek their understanding before receiving foreigners. After gaining the experience of contacting foreigners, they will feel less insecure. Secondly, both $\mathrm{A}$ and $\mathrm{B}$ believe that publicity is the biggest barrier to their inbound businesses as 
they are unclear about the means and platforms of publicity. Among them, A mainly publicizes businesses by posting promotional messages and videos in foreign languages

Table 4. Barriers and Countermeasures in Starting Inbound Tourism

\begin{tabular}{|c|c|c|}
\hline Responses & Barriers & Countermeasures \\
\hline $\begin{array}{l}\text { Concern the attitude of the } \\
\text { surrounding people }(A, B)\end{array}$ & $\begin{array}{l}\text { Surrounding } \\
\text { attitude }\end{array}$ & $\begin{array}{l}\text { Explaining with neighbors } \\
\text { kindly to seek their } \\
\text { understanding }(\mathrm{A}, \mathrm{B})\end{array}$ \\
\hline Where and how to advertise(A) & \multirow{3}{*}{ Publicity } & \multirow{3}{*}{$\begin{array}{l}\text { Posting promotional messages } \\
\text { and videos in foreign languages } \\
\text { on SNS(A) } \\
\text { Collaboration with overseas } \\
\text { travel agencies(B) }\end{array}$} \\
\hline Not good at promoting on SNS(B) & & \\
\hline $\begin{array}{l}\text { Lack of offering information to } \\
\text { overseas by regional departments } \\
\text { (A, B) }\end{array}$ & & \\
\hline $\begin{array}{l}\text { Worry about diet and living habits } \\
(\mathrm{A}, \mathrm{B})\end{array}$ & \multirow{2}{*}{$\begin{array}{l}\text { Service and } \\
\text { activities }\end{array}$} & \multirow{2}{*}{$\begin{array}{l}\text { Learn more about exotic } \\
\text { culture(A) } \\
\text { Information is offered in } \\
\text { advance(B) }\end{array}$} \\
\hline Supply experience activities (A, B) & & \\
\hline $\begin{array}{l}\text { Lack of English guide menu of } \\
\text { town information }(\mathrm{A}, \mathrm{B})\end{array}$ & \multirow{2}{*}{$\begin{array}{l}\text { Matching } \\
\text { Facility }\end{array}$} & \multirow[t]{2}{*}{$\begin{array}{l}\text { Provide pick-up service at } \\
\text { station (A, B) }\end{array}$} \\
\hline $\begin{array}{l}\text { Far from the station, lack of } \\
\text { transportation }(\mathrm{A}, \mathrm{B})\end{array}$ & & \\
\hline
\end{tabular}

Source: Authors' survey

on SNS. As B is not good at using such promotional means as SNS, B mainly receives foreign group tourists in collaboration with travel agencies. Overall publicity assistance is required from the region to promote publicity among overseas tourists. Besides, they are also worried about catering and living habits for foreigners, which can be eliminated with the provision of information on foreign tourists in advance and constant learning about foreign cultures. Finally, there are insufficient facilities for inbound businesses at the regional side. Since most of the farm-stays are in remote rural areas far from the station, local transportation is rather inconvenient. Both A and B provide pick-up services at the station. Meanwhile, the foreign language-version of local information introduction is defective to a large extent. Both A and B can convey local information to tourists through instructions, but the local government should also add online and paper-version information on local food, housing, transportation, and travel in foreign languages.

\section{Discussion}

\subsection{Barriers and Supports in Starting Farm-stay Businesses and Inbound Tourism}

In the above analysis, the study cites two cases of LVC and clarifies the barriers and received supports in the process of their entrepreneurship. Fig. 1 shows the flowchart of the barriers and supports in the business-starting process. Thus, the first stage of barriers is the basic stage, consisting of the barriers encountered in local rural life. In the process of overcoming barriers in daily life, the LVC established networks with local governments and local associations and won trust from local residents. The first stage is 
a foundational phase for the migrants to accommodate to the migrating life in the local areas. Second, in the second stage of preparing to start a business, the connection network

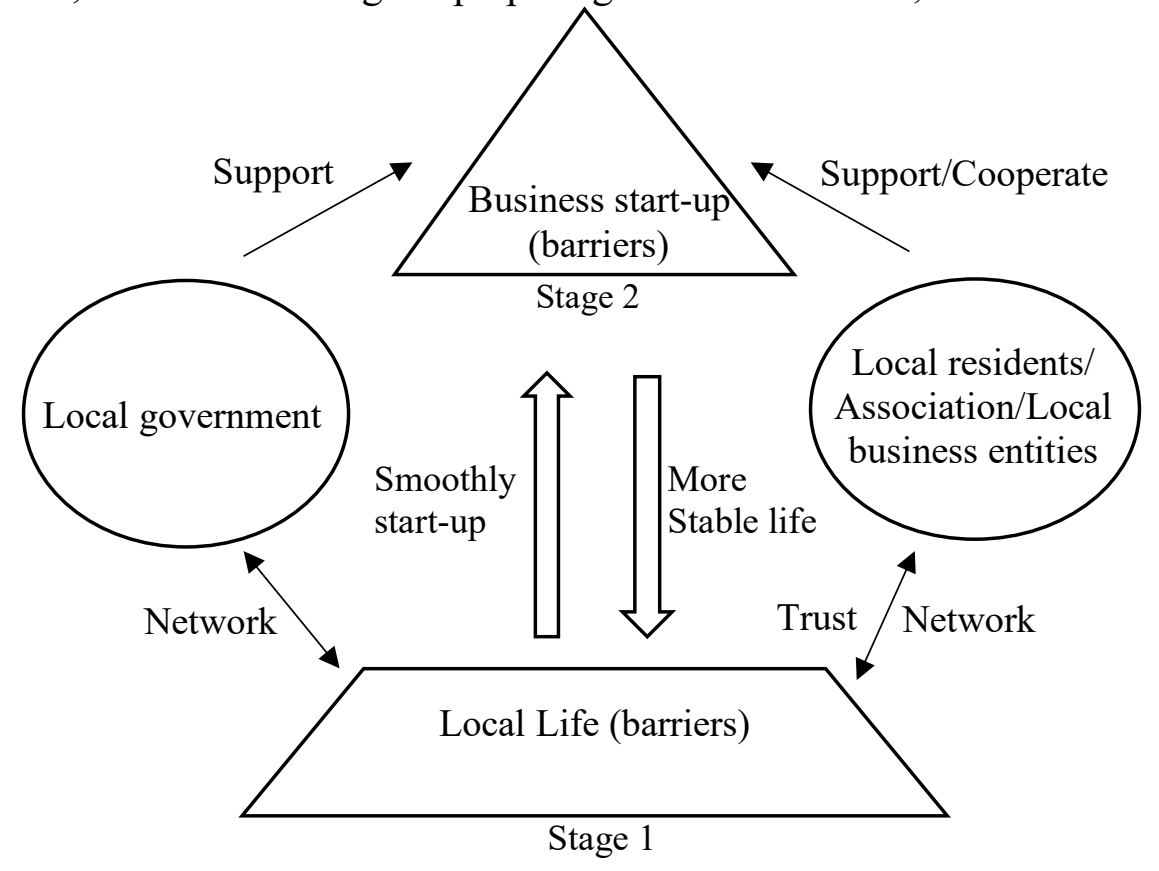

Fig.1 Barriers and Supports in the Business Start-up Process

and the bridge of trust established in overcoming life barriers in the first stage can help settle the barriers more smoothly to starting a new business. Cooperation from the local residents and local relevant entities help to start the business. Finally, by settling entrepreneurial barriers, migrants have also finally expanded exchanges and connections with diversified local business entities and local residents, thus establishing a more stable and trustworthy relationship and offering support to a more stable and high-quality life in local areas.

Regarding the inbound tourism businesses, young migrants mostly have relatively good education experience and exchange experience with foreigners. They have somewhat learning abilities and the ability to accept alien cultures. They also have relatively high intentions to receive foreigners. Therefore, they have smaller barriers in psychological aspect, communication and information acquisition when receiving foreign tourists. However, there is still a big obstacle in terms of publicity, as they attract foreign tourists through their own promotion and cooperation with travel agencies in the two cases. However, they still need the regional relevant sectors to offer integrated publicity about the whole region to achieve better publicity through "personal + cooperation with external travel agencies + regional support". Targeting the transportation and tourism information provision to foreigners, it is also impossible for individuals to do so with their own effort. Regional relevant sectors should offer support to perfect facilities for foreign tourists. In starting the inbound businesses, it is also essential for migrants to establish a good relationship with the local authorities. Based on this, they can cooperate with the regional departments to facilitate inbound businesses. Additionally, despite the negative impact exerted by the COVID-19 epidemic, the inbound businesses have been temporarily suspended. Publicity among foreigners can still go on, paving the way for 
future inbound businesses. In the future, in the starting of farm-stay businesses and inbound tourism, safety concerns may become a major obstacle to the development of the businesses due to the impact of the epidemic.

\subsection{Reflection on Issues and Conditions When Ordinary Migrants Start New Businesses}

The study chose to analyze and introduce the cases of LVC with many entrepreneurial cases attracting wide attention. Through analysis of LVC business-starting process, this research spreads the experience to the entrepreneurship of ordinary migrants. We usually think that ordinary migrants will encounter daunting local life and business start-up barriers. LVC's career experiences in the local region enable them to be smoothly guided and assisted by local governments and associations. Local residents will also trust them because of their identity as LVC in the local area, thus helping them relatively quickly overcome life barriers and guaranteeing smooth entrepreneurship. For the ordinary migrants, when they want to start new businesses, they also have the barriers in local life and business start-up. Therefore, in the case of ordinary migrants, before they start businesses, a sufficient amount of time is a critical factor in their accommodation to local life. They need processes to overcome the local life barriers and win the trust in the local areas at first. Through participation in more local activities and exchanges with local residents, migrants can gradually obtain mutual understanding and tolerance, establish relationships and the sense of trust in local regions, overcome life barriers, and finally step into entrepreneurship.

\section{Conclusion}

As the inadequate current studies on the barriers and countermeasures to starting businesses in rural areas and inadequate studies on the starting phase of farm-stay businesses and inbound tourism from the perspective of migrants, this study clarified the barriers and supports from the perspective of migrants in the process of starting farm-stay businesses with inbound tourism in rural areas, which mainly include barriers to both migrating life and starting new businesses. The regional connection network and bridge of trust established in the process of overcoming the migrating life barriers can help to remove barriers in entrepreneurship. Meanwhile, overcoming the barriers to receiving overseas tourists also requires the establishment of regional relations. For the migrants, they need more time and a better process to blend in the local life and establish good relations with regions before starting the businesses.

This research provides some reference on the study of the barriers and supports to value creation activities by LVC, as well as the study on the barriers and promotion factors for entrepreneurship and a stable life for migrants. Owing to the uniqueness of the selected research object, the results have some limitations. In future studies, it is necessary to choose cases on a wide variety of objects for analysis, thereby clarifying the issues encountered by migrants in starting new businesses and the conditions for promoting entrepreneurship are underway.

\section{Acknowledgments}

The authors sincerely express our gratitude to the owners of the farm-stays in Okumo area, Tambasasayama city and Shimoichi town, Yoshino, for their great assistance during the survey. 


\section{Notes}

Note 1): System overview of LVC: Individuals who transfer their residence from cities to less favored areas such as lower-population zones and move to these locations are designated as members of the "Local Vitalization Cooperator" by the local government. This group will reside in the area for a fixed period, supporting reactivation through activities such as development, sales, and PR for local brands and products, engaging in agriculture, forestry, and fisheries industry work, and cooperating with lifestyle assistance for local residents, while working to drive new settlement. Membership in the LVC is generally designated by the local government for a period of between one and three years.

Note 2): For individuals who either start up or take over businesses in the same area as their Local Vitalization Cooperator activities within one year before or after the conclusion of their squad membership period, a subsidy of up to one million yen per person for expenses involved in the applicable startup or succession will be provided during the final year of squad membership or the year after the conclusion of the applicable membership period. However, this is limited to a single fiscal year for each person.

\section{References}

Fielden, S.L., Davidson, M.J., and Makin, P.J., 2000. Barriers Encountered During Micro and Small Business Start-up in North-West England. Journal of Small Business and Enterprise Development, 7(4): 295-304 http://doi.org/10.1108/EUM0000000006852

Furusato Returning Assistance Center, 2018. Trends in migration consultation, and. ranking of expected migration areas, Available at:

http://www.furusatokaiki.net/wp/wp-content/uploads/2019/02/ webnews20190219 furusato ranking.pdf, Accessed on March 29, 2020

Iwasaki, M., Shimizu, N., Hoshino, S., and Onitsuka K., 2017. Study on Current Situation of Inbound Tourism Utilizing Rural-inns in Kyoto Prefecture. Journal of Rural Planning, 26: 235-241. https://doi.org/10.2750/arp.36.235.

Kim, J., Mitsuhashi, N., Fujimoto, N., 2006. The Actual Condition of the Farm Inn in Hilly and Mountainous Areas: Case of Ajimu Town, Usa City. Journal of Rural Planning, 25: 335340. http://doi.org/10.2750/arp.25.335

Kuwamara, Y. and Nakajima, M., 2016. Research Trends and Perspectives on Projects of Supporters for Rural Regeneration. Journal of Rural Planning, 35(2):105-110

Ministry of Internal Affairs and Communications (2020): Results of the survey on the status of settlement of the Local Vitalization Cooperator, Available at: https://www.soumu.go.jp/main content/000664505.pdf, Accessed on April 6, 2020

Park, H., and Takahashi. E., 2009. The Promotion of Green Tourism and its Potential for. Learning - Examples of Farm Inn in Three Regions of Fukushima Prefecture. Annals of Tohoku University Graduate School of Education, 58(1):307-331.

Sakai, F., Tatemi, J., Tsutsui, K., 2020. Support for Entrepreneurial Migration to Rural. Areas: Example of Tamba City, Hyogo Prefecture. E-journal GEO, 15(1): 14-28. http://doi.org/10.4157/ejgeo.15.14

Shishido, Y. and Sanbe, H., 2019. Settlement and Entrepreneurship by Local Vitalization Cooperator. The Municipal Problems,110(6): 80-89.

Sloka. B., Kantane. I., Jermolajeva. E., and Avotins. V., 2016. Analysis of Barriers for. Business Start. European Integration Studies, 10: 145-156. http://dx.doi.org/10.5755/j01.eis.o.10.14570 
Tsutsui, K., Sakuma, Y., and Kasami, K., 2016. Community Development with Migrants into Rural Areas under the Social Trend on "Den-en Kaiki - Return to Rural Living".Geographical Sciences, 71(3):156-165.

Tsutsui, K., Sakuma, Y., and Kasami, K., 2015. Regional Regeneration by Business in Rural Community of In-migrants from Urban Areas. Journal of Rural Planning, 34(1): 45-50. http://doi.org/10.2750/arp.34.45

Tsutsui, K. and Sawabata, T., 2010. Perspective of "Green Tourism" for Foreign Tourists. in Rural Japan: From the Viewpoint of Marketing Research. E-journal GEO, 5(1): 35-49. https://doi.org/10.4157/ejgeo.5.35.

Yasumoto, M., 2014. Endogenous Regional Development and Immigrant. Entrepreneurship Potential: A Case Study of Tourism in Tochigi Prefecture Nasu-machi. Journal of Urban Management and Local Government Research, 29(1): 26-39.

Zushi, N. and Odagiri, T., 2014. Rural Regeneration by Local Support Talents. Tsukub-shobo Publication, Tokyo. 